\title{
Center pivot irrigation management in maize hybrids and the incidence of stalk rot
}

\author{
Irineu E. Kühn ${ }^{1}$, Mayara F. Cotrim² ${ }^{2}$ Ricardo Gava ${ }^{3}$, Rita de C. F. Alvarez ${ }^{3}$, Job T. de Oliveira ${ }^{4}$ \& \\ Paulo E. Teodoro ${ }^{3}$ \\ ${ }^{1}$ Universidade Estadual Paulista/Departamento de Engenharia, Irrigação e Drenagem. Botucatu, SP, Brasil. E-mail: irineuk@live.com - ORCID: 0000- \\ $0002-1222-7750$ \\ ${ }^{2}$ Universidade Estadual Paulista/Faculdade de Engenharia do Campus de Ilha Solteira. Ilha Solteira, SP, Brasil. E-mail: mayaracotrim5@gmail.com. \\ ORCID: 0000-0003-0878-4922 \\ ${ }^{3}$ Universidade Federal de Mato Grosso do Sul. Chapadão do Sul, MS, Brasil. E-mail: ricardo.gava@ufms.br (Corresponding author) - ORCID: 0000-0001- \\ 6268-5728; rita.alvarez@ufms.br - ORCID: 0000-0002-1655-9939; paulo.teodoro@ufms.br - ORCID: 0000-0002-8236-542X \\ ${ }^{4}$ Universidade Federal do Maranhão. Chapadinha, MA, Brasil. E-mail: job.oliveira@hotmail.com - ORCID: 0000-0001-9046-0382
}

\begin{abstract}
This study aimed to verify the incidence of Fusarium spp. in commercial maize hybrids and irrigation management strategies utilizing center pivot systems. The experiment was carried out during the second season in a randomized block design with a split-plot arrangement with five maize hybrids (2B810, MG580, AS1633, DKB290, and AG8544). The plots were irrigated with five frequencies (1, 2, 3, 4, and 5 days) in one experiment, and five water depths (at 25, 50,75, 100, and 125\% of crop evapotranspiration) in another experiment. Plant height, ear insertion height, moisture at harvest time, yield, and incidence of stalk rot were evaluated. Neither irrigation frequency nor irrigation depth influenced the incidence of disease. The one-day irrigation frequency provided the highest yield for maize hybrids. Hybrid 2B810 showed the highest yield and the lowest incidence of the disease.
\end{abstract}

Key words: Zea mays, fungal disease, precision irrigation

\section{Manejo da irrigação sob pivô central em híbridos de milho e a incidência de podridão de colmo}

\begin{abstract}
RESUMO: Este estudo foi realizado com o objetivo de avaliar a incidência de Fusarium spp. em híbridos comerciais de milho e manejos de irrigação por pivô central em segunda safra. O experimento foi conduzido em delineamento de blocos casualizados em esquema de parcelas subdivididas, sendo as parcelas constituídas pelos manejos de irrigação com cinco frequências (1, 2, 3, 4, 5 dias, primeiro experimento) e cinco lâminas d'água (25, 50,75, 100 e 125\% da evapotranspiração da cultura) e as subparcelas com cinco híbridos de milho (2B810, MG580, AS1633, DKB290 e AG8544), em quatro repetições. Foram avaliadas altura de planta, altura de inserção de espigas, umidade no momento da colheita, produtividade e incidência de podridão no colmo. Tanto as a frequências de irrigação como as lâminas de irrigação não influenciaram a incidência da doença. A frequência de irrigação de um dia proporcionou o maior rendimento de híbridos de milho. O híbrido 2 B810 apresentou o maior rendimento e a menor incidência da doença.
\end{abstract}

Palavras-chave: Zea mays, doença fúngica, irrigação de precisão 


\section{INTRODUCTION}

In Brazil, the incidence of diseases in maize crops has increased over the years. Pinto (2005) relates this phenomenon to climatic changes and common practices adopted in the midwest region of the country, such as no-tillage and irrigation systems, sowing times, and crop succession. These changes encourage edaphoclimatic conditions favorable to pathogens and the preservation of inocula, promoting plant disease.

Fusarium spp. is a fungus that survives in the soil through its resistance structures, until it finds a host. Moreover, it can survive in seeds (Ramos et al., 2014). In the latter case, measures to combat fungus are seed analysis and the use of chemical treatments (Costa et al., 2003). Munkvold (2003) stated that Fusarium spp. is one of the most important pathogens of maize crops, as it is related to diseases such as root rot, seedling death, and stalk and ear rot, which can cause decreases in crop yield and grain quality.

In addition to the ability of Fusarium spp. to survive in soil, a wide range of plant species can serve as hosts for it. Pinto (2006) stated that proper soil preparation and suitable fertilization can help prevent nutritional stress and facilitate maize plant resistance to the fungus. However, the author cites that the most effective measure is the use of resistant hybrids. In addition, the application of fungicide products is an efficient practice for maintaining crop health.

In the midwest region of Brazil, maize is predominantly grown during the second harvest, after a soybean harvest. During the maize-growing period, the crop usually experiences a water deficit. Bergamaschi et al. (2004) found that even during climatically favorable years, grain yield might decrease due to water stress during the critical period between pre-flowering to the start of grain filling. Scientific research advancing the genetic improvement and biotechnology of maize crops has contributed to increasing their adaptation to water shortage scenarios (Langner et al., 2019). Maximum technical efficiency of irrigation depths has increased grain yield from 9.9 to $41 \%$ (Ben et al., 2019).

Based on these factors, the use of irrigation for water supplementation avoids stress in maize plants, resulting in maximized crop yields. Therefore, this study aimed to verify the incidence rates of Fusarium spp. in the second harvests of commercial maize hybrids managed with the aid of center pivot irrigation.

\section{Material and Methods}

Two experiments were carried out at Fundação de Apoio à Pesquisa Agropecuária de Chapadão, Chapadão do Sul, Mato Grosso do Sul ( $18^{\circ} 46^{\prime} 49^{\prime \prime}$ S, 52 38' 51" W, altitude - 810 m), Brazil, during the 2016 crop season. The first experiment aimed to evaluate the effect of irrigation frequency on the incidence of
Fusarium spp., while the second experiment evaluated the effect of water depth on the pathogens that attack maize plants. The climate of the region is classified as Aw (tropical with dry winter and rainy summer), according to Köppen's classification, with an average annual temperature of $25^{\circ} \mathrm{C}$ and average rainfall between 1600 and $1800 \mathrm{~mm}$. The soil is classified as Oxisol, with a high clay content (Table 1).

The hydro-physical characteristics necessary for appropriate irrigation management were obtained from the water retention curves of the soil, using a Richards extractor. The field capacity for the $0-0.15$ and $0.15-0.30 \mathrm{~m}$ layers were 0.413 and $0.383 \mathrm{~cm}^{3} \mathrm{~cm}^{-3}$, respectively. The water content equivalent to the wilting point in these layers was 0.282 and $0.262 \mathrm{~cm}^{3} \mathrm{~cm}^{-3}$; the real available water (RAW) was 1.76 and $1.74 \mathrm{~mm} \mathrm{~cm}^{-1}$, and the soil and particle density, determined by the volumetric ring method, was 1.34 and $1.44 \mathrm{~kg} \mathrm{dm}^{-3}$, respectively.

Each experiment was carried out in a randomized block design, with treatments arranged in subplot schemes. The main factor in the first experiment was composed of five irrigation frequencies $(1,2,3,4$, and 5 days). The main factor of the second experiment was composed of five water depths $(25,50$, 75,100 , and $125 \%$ of the crop evapotranspiration - ETc. In both experimental subplots for each region, the secondary factor was composed of five of the most used maize hybrids (2B810, MG580, AS1633, DKB290, and AG8544) in that region. The plots consisted of five $5-\mathrm{m}$ rows spaced at $0.45 \mathrm{~m}$. The useful areas in each experiment were defined as two central rows of crop, and excluding a $1.5 \mathrm{~m}$ zone at each end.

Mechanized sowing was carried out in each experiment on April 08, 2016. The number of sown seeds was sufficient to obtain a population of 60,000 plants per hectare in a no-tillage system. The mineral fertilization in seed furrows consisted of $150 \mathrm{~kg} \mathrm{ha}^{-1}$ of monoammonium phosphate. Thirty days after emergence, $60 \mathrm{~kg} \mathrm{ha}^{-1}$ of $\mathrm{K}_{2} \mathrm{O}$ in the form of potassium chloride and $30 \mathrm{~kg} \mathrm{ha}^{-1}$ of nitrogen in the form of urea were applied as topdressing. Sixty days after emergence, nitrogen was applied at the same dose.

Seeds were treated with imidacloprid $\left(150 \mathrm{~g} \mathrm{~L}^{-1}\right)+$ thiodicarb (450 $\left.\mathrm{g} \mathrm{L}^{-1}\right)$, at a dose of $0.35 \mathrm{~L} \mathrm{ha}^{-1}$, and carboxin

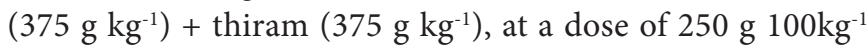
of seeds. Phytosanitary treatments were performed during the experiment, depending on the occurrence of pests, by applying indoxacarb $\left(400 \mathrm{~mL} \mathrm{ha}^{-1}\right)$ and diamida $\left(150 \mathrm{~mL} \mathrm{ha}^{-1}\right)$ to control the fall armyworm, and beta-cyfluthrin $\left(12.5 \mathrm{~g} \mathrm{~L}^{-1}\right)$ + imidacloprid $\left(100 \mathrm{~g} \mathrm{~L}^{-1}\right)$, at $800 \mathrm{~mL} \mathrm{ha}^{-1}$ to control corn leafhopper and bedbugs.

The center pivot irrigation system used in this study was managed based on climate characteristics, following the methodology of Penman-Monteith-FAO, according to Allen et al. (1998). The definitions of the crop coefficients and root system depth of each subperiod (Table 2) followed the

Table 1. Hydro-physical soil attributes of the experimental area at 0-0.15 and 0.15-0.30 m depths

\begin{tabular}{|c|c|c|c|c|c|c|c|c|c|c|}
\hline \multirow{2}{*}{$\begin{array}{l}\text { Layer } \\
(\mathrm{cm})\end{array}$} & FC & RWC & \multirow{2}{*}{$\begin{array}{c}\text { TAW } \\
\left(\mathrm{mm} \mathrm{cm}^{-1}\right)\end{array}$} & SD & PD & \multirow{2}{*}{$\begin{array}{l}\mathrm{TP} \\
(\%)\end{array}$} & \multicolumn{3}{|c|}{ Granulometry (dag kg-1) } & \multirow{2}{*}{ Texture } \\
\hline & \multicolumn{2}{|c|}{$\left(\mathrm{cm}^{3} \mathrm{~cm}^{-3}\right)$} & & & & & Sand & Silt & Clay & \\
\hline $0-15$ & 0.43 & 0.282 & 1.76 & 1.34 & 2.65 & 53.6 & 39.24 & 6.68 & 54.08 & \multirow{2}{*}{ Clayey } \\
\hline $15-30$ & 0.383 & 0.262 & 1.74 & 1.44 & 2.65 & 48.4 & 36.76 & 4.56 & 58.68 & \\
\hline
\end{tabular}

FC - Field capacity moisture at the water matric potential ( $\left.\Psi_{\mathrm{m}}\right)$ of $0.3 \mathrm{~atm}$; RWC - Residual water content (RWC) at a $\Psi_{\mathrm{m}}$ of 15 atm; TAWC - Total available water; SD - Soil density; TP - Total soil porosity; PD - Particles density 
Table 2. Crop coefficients (Kc) for maize for each phenological stage

\begin{tabular}{lc|}
\hline \multicolumn{1}{c}{ Stage (DAE interval) } & Kc \\
\hline Up to 4 visible leaves (0-18) & 0.32 \\
4-8 visible leaves and still attached to the stem (19-37) & 1.07 \\
8-12 visible leaves and still attached to the stem (37-50) & 1.50 \\
Tasseling, flowering, and pollination (51-64) & 1.43 \\
End of pollination to dough grains (64-77) & 1.25 \\
Dough grains to dent or farinaceous grains (78-89) & 1.01 \\
Farinaceous grains to flint grains (90-99) & 0.39 \\
\hline Flint grains to the physiological maturity (100-110) & 0.23 \\
\hline
\end{tabular}

recommendations of Detomini et al. (2009), using a gradual variation of the passage from one subperiod to the other in function of the days after emergence.

The water balance remained in deficit for almost the entire cycle of rainfed crops (Figure 1), with low rainfall frequency and volume, totaling $203.0 \mathrm{~mm}$ - a much lower volume than maize requires during its growing period. The required amount of water depends on the cycle of the hybrid and the climatic conditions, which, can vary from 500 to $800 \mathrm{~mm}$ according to Doorenbos \& Kassam (1994). Therefore, no control treatment (without irrigation) was carried out.

From the sowing day up to 20 days after sowing, no rainfall was recorded, which significantly affected the initial stages of the crop in treatments with less irrigation. During most of the cycle, the value for water storage was far below that of the real available water (RAW), keeping the plants at the residual water content (RWC). This water stress condition inhibited the development of the plants for an extended period, and at 45 days after sowing (V7 stage), all the plants died.

The air temperature (maximum and minimum) and the air relative humidity for all experimental periods are presented in Figure 2.

According to Figure 2, the lower air relative humidity was verified between the reproductive period of the cycle.

Irrigation frequencies were based on the interval defined in each treatment $(1,2,3,4$, and 5 days) by applying the accumulated value of ETc for the period.

Water depths were artificially raised only when the water balance of the crop was close to the lower limit of the RAW. Thus, irrigation $(25,50,75,100$, and $125 \%$ of the ETc accumulated in the period) was performed only when the plants consumed all the readily available water.

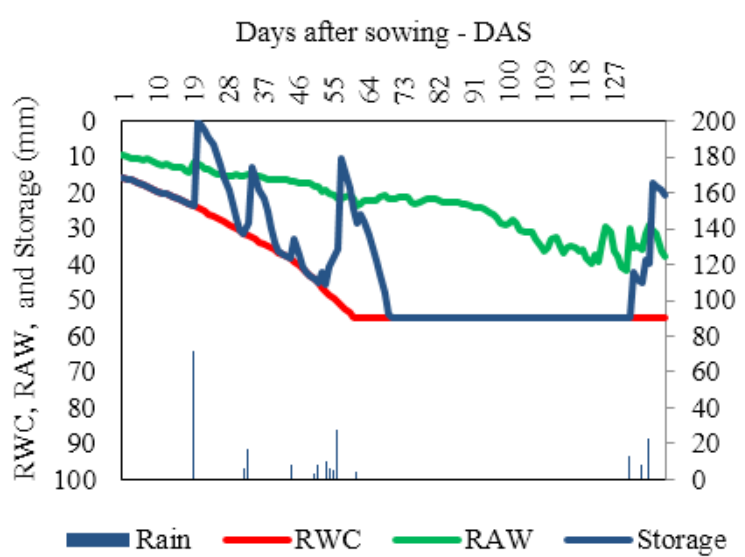

Figure 1. Residual water content (RWC), real available water (RAW), soil water storage (Storage) and rainfall for maize crop in the rainfed condition, during the study period

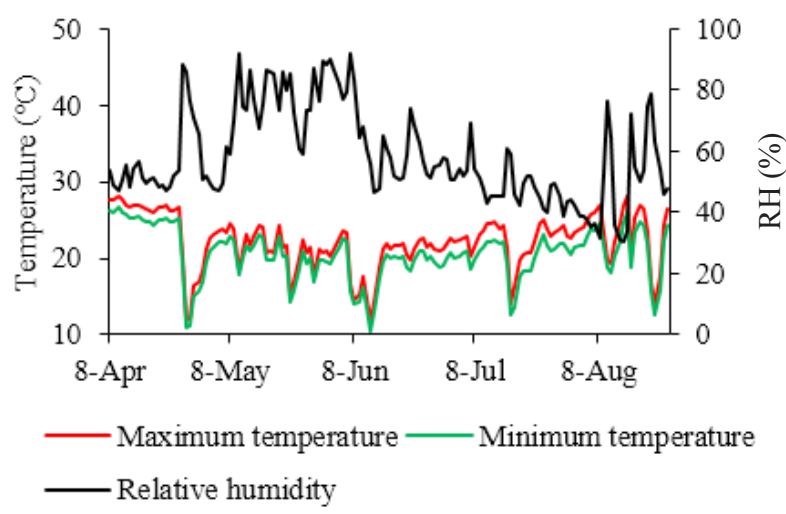

Figure 2. Air maximum and minimum temperature, and air relative humidity $(\mathrm{RH})$ during the experimental period

The total water applied in each treatment is presented in Table 3, showing the differences in each management strategy of irrigation frequency and water depth.

Stalk rot incidence was evaluated at the milky grain stage, 84 days after emergence, by the presence and absence method. This study evaluated 40 plants per plot to verify signs of the disease in the stem of each plant and to calculate the percentage of disease incidence for each treatment.

Plant and ear insertion heights were evaluated during the physiological maturation stage in 10 plants randomly selected from the useful area of each plot, by measuring the distance from the soil surface to the last leaf and ear insertion, respectively. Harvesting first began on August 25, 2016, but each hybrid was only harvested when it reached maturity. Grain yield was obtained by weighing the grains from the useful area of the plots, correcting to $13 \%$ of moisture, and subsequently converting the values to $\mathrm{kg} \mathrm{ha}^{-1}$.

The data were subjected to an analysis of variance test. The hybrid means were compared by Tukey's test, whereas the irrigation frequency and water depths were subjected to regression analysis. Afterward, Pearson's correlations between the evaluated variables were estimated. The correlation network was used to graphically express the results the proximity between the nodes (traces) is proportional to the absolute correlation value among these nodes. Edge thickness was controlled for using the estimates of correlation, where positive correlations are highlighted in green and negative correlations are colored in red. Finally, principal component analysis (PCA) was carried out for the treatments of both experiments (irrigation frequency $\times$ maize hybrid and irrigation depths $\times$ maize hybrid). These analyses were performed using the free software RBio (Bhering, 2017).

Table 3. Total water applied (TWA) in each management of irrigation frequencies and water depths

\begin{tabular}{|c|c|c|c|c|c|c|c|c|c|}
\hline \multicolumn{5}{|c|}{ Irrigation frequencies (days) } & \multicolumn{5}{|c|}{ Water depths (\%) } \\
\hline 1 & 2 & 3 & 4 & 5 & 25 & 50 & 75 & 100 & 125 \\
\hline \multicolumn{10}{|c|}{ TWA (mm) } \\
\hline 381 & 359 & 331 & 310 & 294 & 93 & 173 & 252 & 331 & 410 \\
\hline
\end{tabular}

\section{Results AND Discussion}

Significant differences $(\mathrm{p} \leq 0.05)$ in irrigation frequency were observed only for the grain moisture at harvest time and grain yield (Table 4). The maize hybrids had different results for 
all evaluated variables. No significant interaction was observed between these factors, indicating that the hybrids had a similar response regardless of irrigation frequency.

The higher the irrigation frequency, the lower the grain moisture at harvest time (Table 4 ). This reinforces the hypothesis that the more intense the water regime at harvest time, either through irrigation or natural rainfall, the higher the moisture content of maize grains (Bergamaschi et al., 2004). Thus, both the use of hybrids and irrigation resulted in moisture percentages higher than that recommended.

The highest grain yield was obtained at the 1- and 2-day irrigation frequencies. When compared with the lowest GY (3-day irrigation frequency $\left.=4.057 \mathrm{t} \mathrm{ha}^{-1}\right)$, the results were $22.36 \%$ and $17.70 \%$ higher, respectively (Table 3). Bergamaschi et al. (2006) stated that if the water deficit period coincides with the critical period of the maize crop, from pre-flowering to grain filling, grain yield may be affected. This is related to the fact that lower grain yields are obtained with decreases in irrigation frequencies, resulting in the high incidence of diseases reported in this study.

For plant height, the hybrid $2 \mathrm{~B} 810$ had 23\% higher plant population when compared to the hybrid with the lowest plant height (MG 580). Although the irrigation depths did not differ significantly for plant height, other studies indicate the importance of water management in this crop (Kappes et al., 2011; Agostinho, 2011; Vieira et al., 2013). Rosa et al. (2015) studied the behavior of 50 maize hybrids in response to two fertilization levels and verified mean heights of 213.1, 215.6, and $226.0 \mathrm{~cm}$ for hybrids DBK290, 2B810, and AS1633, respectively, in the region of Lucas do Rio Verde, MT, Brazil (Table 3).

Ear insertion height had different behavior from that of plant height. The tallest hybrid had the highest ear insertion height, as can be seen for the hybrid 2B810 $(99.16 \mathrm{~cm})$. According to Sangoi et al. (2002), a shorter distance between

Table 4. Means and summary of analysis of variance for plant height $(\mathrm{PH})$, ear insertion height $(\mathrm{EIH})$, grain moisture at the harvest time $(\mathrm{GMH})$, grain yield (GY), and incidence of disease (ID) for irrigation frequency

\begin{tabular}{|c|c|c|c|c|c|}
\hline & PH & EIH & \multirow{2}{*}{$\begin{array}{l}\text { GMH } \\
(\%)\end{array}$} & \multirow{2}{*}{$\begin{array}{c}\text { GY } \\
\left(t h a^{-1}\right)\end{array}$} & \multirow{2}{*}{$\begin{array}{l}\text { ID } \\
(\%)\end{array}$} \\
\hline & \multicolumn{2}{|c|}{ (cm) } & & & \\
\hline \multicolumn{6}{|l|}{$\begin{array}{l}\text { Irrigation frequency } \\
\text { (days) }\end{array}$} \\
\hline 1 & 193.46 & 99.49 & 25.45 & 5.226 & 69.25 \\
\hline 2 & 192.83 & 103.50 & 26.15 & 4.930 & 74.50 \\
\hline 3 & 186.58 & 99.83 & 24.18 & 4.057 & 70.62 \\
\hline 4 & 187.91 & 103.08 & 24.11 & 4.264 & 72.00 \\
\hline 5 & 196.00 & 104.58 & 22.57 & 4.379 & 75.12 \\
\hline \multicolumn{6}{|l|}{ Hybrids } \\
\hline 2B810 & $208.83 \mathrm{a}$ & 99.16 bc & $30.50 \mathrm{a}$ & $7.691 \mathrm{a}$ & $25.87 \mathrm{~d}$ \\
\hline MG580 & $168.41 \mathrm{~d}$ & $93.16 \mathrm{c}$ & 24.01 b & $3.848 \mathrm{~b}$ & $85.75 b$ \\
\hline AS1633 & $183.21 \mathrm{C}$ & $100.91 \mathrm{~b}$ & 24.44 b & $4.183 \mathrm{~b}$ & $77.25 \mathrm{C}$ \\
\hline DKB290 & $194.50 \mathrm{~b}$ & $105.83 \mathrm{ab}$ & 20.42 C & $3.265 \mathrm{~b}$ & $79.87 \mathrm{bc}$ \\
\hline \multirow[t]{2}{*}{ AG8544 } & $201.83 \mathrm{ab}$ & $111.41 \mathrm{a}$ & $23.10 \mathrm{~b}$ & $3.868 \mathrm{~b}$ & $92.75 \mathrm{a}$ \\
\hline & & & $p$ Ftest & & \\
\hline Irrigation frquency $(F)$ & $0.4764^{\mathrm{ns}}$ & $0.7132^{\mathrm{ns}}$ & $0.0161^{*}$ & $0.0374^{*}$ & $0.2670^{\text {ns }}$ \\
\hline Hybrids $(\mathrm{H})$ & $0.0000^{* *}$ & $0.0000^{* *}$ & $0.0000^{* *}$ & $0.0000^{* *}$ & $0.0000^{* *}$ \\
\hline $\mathrm{F} \times \mathrm{H}$ & $0.4224^{\text {ns }}$ & $0.1107^{\text {ns }}$ & $0.1970^{\text {ns }}$ & $0.6741^{\text {ns }}$ & $0.2780^{\text {ns }}$ \\
\hline CV $(\%)$ & 9.58 & 13.73 & 11.59 & 25.130 & 12.69 \\
\hline Mean & 191.36 & 102.09 & 24.49 & 4.571 & 72.30 \\
\hline
\end{tabular}

$\mathrm{ns},{ }^{*},{ }^{* *}-$ Not significant and significant at $\mathrm{p} \leq 0,05$ and $\mathrm{p} \leq 0,01$ by $\mathrm{F}$ test the soil and the ear insertion contributes directly to the reduction of stalk breakage, which occurs in taller plants. Thus, taller hybrids such as AS1633, DKB 290, and AG8544 had higher ear insertion height and may be more susceptible to breakage (Table 3).

Over $70 \%$ of the crop comprising the hybrids DKB290, MG580, AG8544, and AS1633 were attacked by disease, and $90 \%$ of the hybrid AG8544 was diseased (Table 4). These hybrids had high lodging due to stalk rot. Moreover, the ears were attacked by fungi, causing a decrease in yield. Pinto (2005) stated that the incidence of fungi during the pre-harvest stages of maize can directly affect grain yield by causing ear rot. Stefanello et al. (2012) found a 19.3-27.4\% incidence of disease in three maize hybrids (Celeron, Penta, and Status) during one summer harvest. These results demonstrate that the incidence of Fusarium spp. is more associated with genetic factors than with water availability during the maize cycle.

This is evidenced by the analysis of the grain yield of 2B810. This hybrid had the highest disease incidence $(25.87 \%$ incidence). The yield of the DKB290 was $57.54 \%$ lower than the 2B810. Rosa et al. (2017) found yields of 5.589 and 5.740 tha- 1 for hybrids AS1633 and DKB290 in the second maize crop (Table 4). Rosa et al. (2015) also verified that hybrid 2B810 had the highest grain yield among the hybrids they evaluated. Kaman et al. (2011) affirm that the grain yield response of maize depends on the level of deficiency of irrigation and genotypic variability.

Table 5 shows that water depth did not influence the evaluated variables. However, hybrids had a significant effect on all variables $(\mathrm{p} \leq 0.01)$. These results disagree with those reported by Ben et al. (2016), who reported that irrigation affected dry matter, hundred-grain weight, and the highest grain yield of the maize hybrid Dekalb 250 PRO2 maize hybrid for the $100 \%$ ETc irrigation depth. This difference may

Table 5. Analysis of variance for plant height $(\mathrm{PH})$, ear insertion height $(\mathrm{EIH})$, grain moisture at the harvest time $(\mathrm{GMH})$, grain yield (GY), and incidence of disease (ID) for water depths treatments

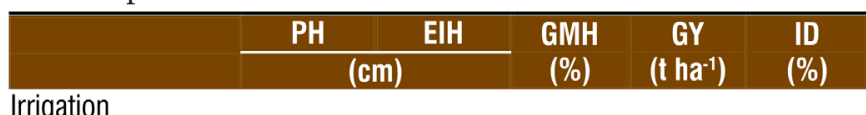

\begin{tabular}{|c|c|c|c|c|c|}
\hline \multicolumn{6}{|l|}{$\begin{array}{l}\text { Irrigation } \\
(\%)\end{array}$} \\
\hline 25 & 199.00 & 107.25 & 21.35 & 4.59 & 73.00 \\
\hline 50 & 199.83 & 104.83 & 21.01 & 4.09 & 79.37 \\
\hline 75 & 207.16 & 109.75 & 21.21 & 4.69 & 79.75 \\
\hline 100 & 197.91 & 105.00 & 21.96 & 4.50 & 78.12 \\
\hline 125 & 199.16 & 103.71 & 19.92 & 4.17 & 76.62 \\
\hline \multicolumn{6}{|l|}{ Hybrids } \\
\hline 2B810 & $215.83 \mathrm{a}$ & $101.29 b c$ & $28.15 \mathrm{a}$ & $8.13 \mathrm{a}$ & $36.37 \mathrm{~d}$ \\
\hline MG580 & $173.16 b$ & 99.66 c & $20.24 b$ & $3.60 a b$ & $97.25 \mathrm{a}$ \\
\hline AS1633 & $201.75 b$ & $108.75 \mathrm{a}$ & $18.60 \mathrm{~b}$ & $3.66 a b$ & $78.50 \mathrm{C}$ \\
\hline DKB290 & $201.83 b$ & $107.66 \mathrm{ab}$ & $17.98 b$ & $2.60 \mathrm{~b}$ & $85.87 \mathrm{bc}$ \\
\hline \multirow[t]{2}{*}{ AG8544 } & $210.50 \mathrm{ab}$ & $113.16 \mathrm{a}$ & $20.43 b$ & $4.06 \mathrm{ab}$ & $88.87 \mathrm{~b}$ \\
\hline & & & F test & & \\
\hline Irrigation & $0.0556^{\text {ns }}$ & $0.3253^{\text {ns }}$ & $0.4978^{\text {ns }}$ & $0.5030^{\text {ns }}$ & $0.1453^{\text {ns }}$ \\
\hline Hybrids & $0.0000^{* *}$ & $0.0000^{* *}$ & $0.0000^{* *}$ & $0.0000^{* *}$ & $0.0000^{* *}$ \\
\hline Irrigation $x$ Hybrids & $0.7545^{\mathrm{ns}}$ & $0.3652^{\text {ns }}$ & $0.7567^{\mathrm{ns}}$ & $0.9942^{\mathrm{ns}}$ & $0.3172^{\text {ns }}$ \\
\hline CV (\%) & 4.69 & 8.90 & 16.72 & 28.47 & 10.93 \\
\hline Mean & 200.61 & 106.11 & 21.09 & 4.41 & 77.37 \\
\hline
\end{tabular}

$\mathrm{ns},{ }^{*},{ }^{* *}-$ Not significant and significant at $\mathrm{p} \leq 0,05$ and $\mathrm{p} \leq 0,01$ by $\mathrm{F}$ test 
be related to the high incidence of diseases detected in the present experiment. The water depth $\times$ hybrid interaction for all variables was not significant, indicating a similar response of all hybrids, regardless of water depth.

Similar results were found for hybrid 2B810, which showed significantly higher values for plant height when compared with the other hybrids, followed by the hybrid AG8544 (Table 5). Shioga et al. (2015) observed higher means for plant height than those of the present study for the lowest hybrid (MG580). These same authors found no significant change in lodging or breakage rates for this cultivar, compared to others.

It is important to highlight that the highest water productivity was obtained with irrigation deficit strategies, which may be a suitable approach in water resource management to increase the efficiency of water use; applicable in situations with water limitations (Vian et al., 2016; Martin et al., 2012). However, Gava et al. (2018) warn that in the case of sandy soils, the best results will always be for the greatest water depths.

Studying the effects of waterlogging stress on plantpathogen interactions between Fusarium and wheat/barley, testing levels of water in interaction with Fusarium, Martínez et al. (2019) found that excess water always decreases yield, regardless of Fusarium presence.

In general, height correlated with plant ear insertion height insertions between 99.66 and $101.19 \mathrm{~cm}$. However, the hybrid with the highest result for plant height (2B810) did not have the highest result for ear insertion height. A response also reflected in the irrigation frequencies, where hybrid AG8544 had a high value for ear insertion height (Table 5). The ear insertion height should be lower than $1 \mathrm{~m}$ for good structural stability of maize plants. Conversely, Santos et al. (2002) affirmed that the higher the insertion, the better the efficiency of mechanized harvesting, ensuring lower grain losses and higher grain purity.

Figure 3 shows that the lower incidence of stalk rot in hybrid 2B810 hybrid planting may be directly related to grain yield (Table 5). According to Pereira et al. (2005), when disease infestation occurs, grain filling stops, leading to rot, which can culminate in severe yield reduction. Table 4 shows that 78.50 to $97.50 \%$ of disease incidence led to grain yields lower than $4 \mathrm{t} \mathrm{ha}^{-1}$, which is considered a low yield.

Grain yield was higher for hybrid 2B810, with the lowest disease incidence rate (37.39\%), compared to other hybrids (Table 5). Despite the significantly higher yield, other authors reported about $10 \mathrm{t} \mathrm{ha}^{-1}$ grain yield for the same hybrid (Rosa et al., 2015). The mean grain yield for maize in Brazil is approximately $6 \mathrm{t} \mathrm{ha}^{-1}$; however, the mean grain yield of all hybrids was lower than this value, except for hybrid $2 \mathrm{~B} 810$.

Principal component analysis (PCA) revealed the relationships between irrigation management factors of each experiment simultaneously, using a general measure of the hybrid yield in each strategy. The first two principal components were responsible for $88.3 \%$ of the total variance of the variables evaluated. Figure 3 shows the dispersion between the evaluated variables and different irrigation strategies in relation to the first two principal components. The more distant the axial position of the components, the closer the relationship between them. The points in the graph show the relationship of the components based on the proximity between the axes.
Dispersion

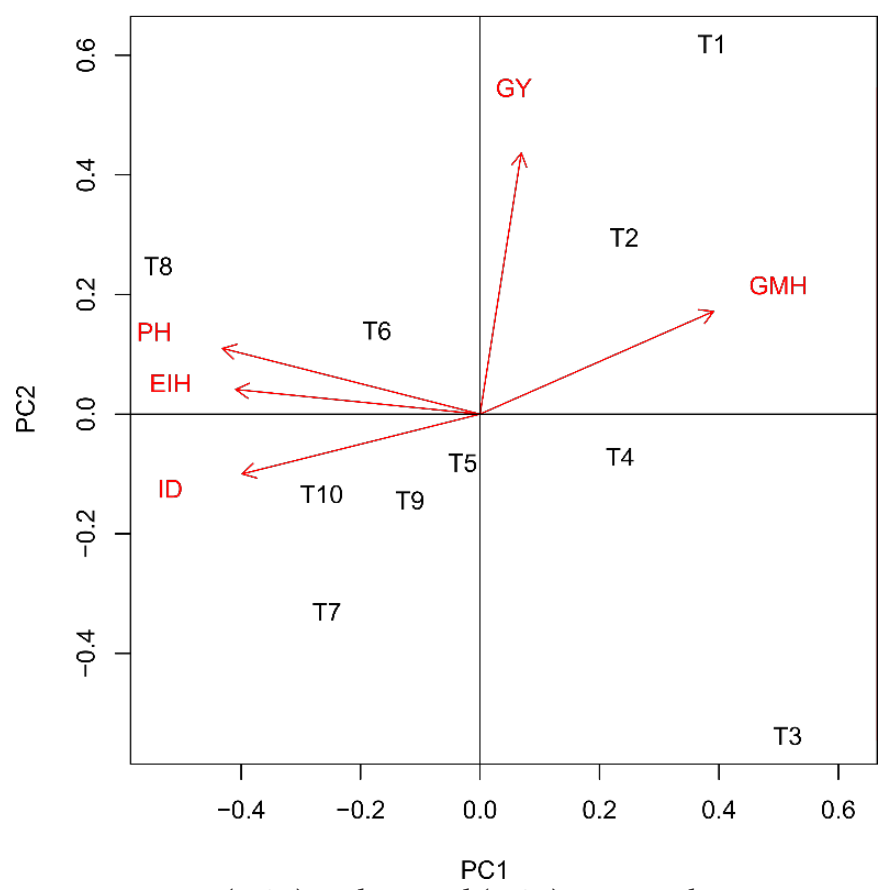

Figure 3. First (PC1) and second (PC2) principal components and dispersion of grain moisture at the harvest time (GMH), grain yield (GY), plant height $(\mathrm{PH})$, ear insertion height $(\mathrm{EIH})$ and incidence of disease (ID), for frequencies of $1,2,3,4$ and 5 days (T1, T2, T3, T4, and T5, respectively) and water depths of 25, 50, 75, 100, and 125\% ETc (T6, T7, T8, T9, and T10, respectively)

Figure 3 shows that the cluster formed by the treatments of 5-day irrigation frequency (T5) and water depths of 25, 50, 75,100 , and $125 \%$ ETc (T6, T7, T8, T9, and T10, respectively) is close to ID and far from GY. These treatments had a high incidence of disease and low yield. In all the plots of these treatments, plants showed stalk rot and ears attacked by fungi, which explains the low grain yield. These results corroborate those of Pereira et al. (2005), who found a yield decrease in response to high severity of fungal diseases in the crop. Roese et al. (2018) point that agrosilvopastoral systems have the potential to reduce the abundance of Fusarium spp. and enhance populations of beneficial microorganisms in the soil. This is important to show that correct management of irrigation can improve the abundance of beneficial microorganisms too.

The GY vector is in the opposite direction to that of ID and close to the T1 and T2 treatments. This fact shows that high incidence of disease compromises grain yield and that the treatments with higher irrigation frequencies resulted in higher grain yields. Bergamaschi et al. (2004) claimed that, from tasseling to the beginning of grain filling, irrigation allows high grain yields and contributes to healthier plants. This result shows the importance of using healthy seeds, especially the choice of tolerant hybrids, as reported by Pereira et al. (2005) and Pinto (2006).

Figure 4 shows the correlation network between the variables evaluated in the two experiments. Grain yield and the incidence of stalk rot have a high correlation. These results are similar to those reported by Pinto (2005), who verified that 


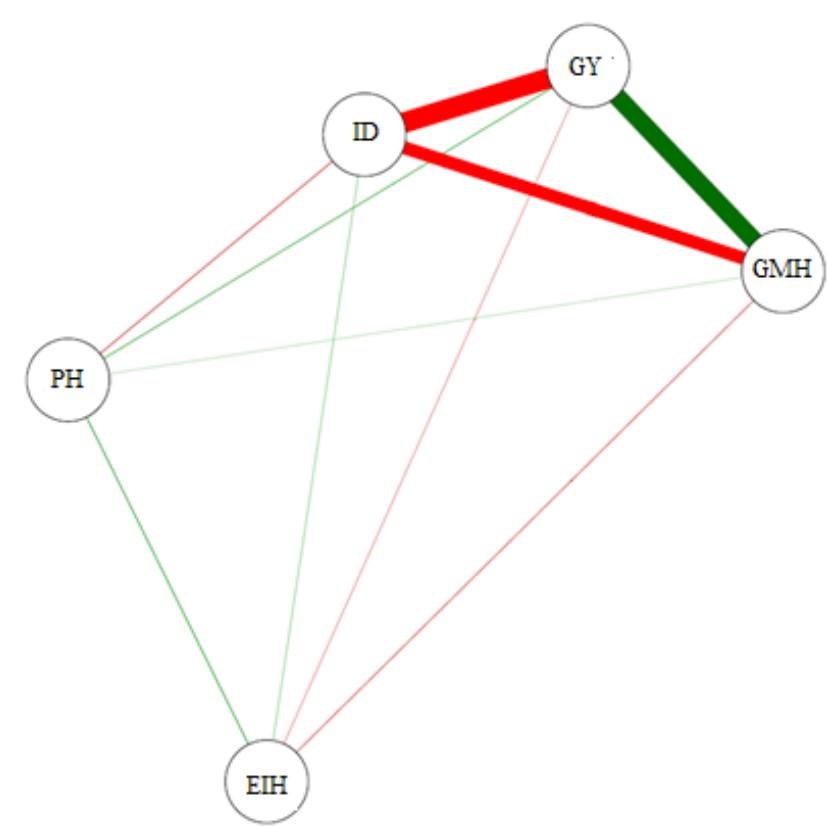

Figure 4. Correlation network of principal components: grain moisture at the harvest time (GMH), grain yield (GY), plant height $(\mathrm{PH})$, ear insertion height (ear insertion height), incidence of disease (ID)

several species of fungus are directly linked to the damage caused to plants and grains, resulting in decreased yields.

\section{Conclusions}

1. The incidence of stalk rot was not influenced by irrigation management strategy. The one-day irrigation frequency provided the highest grain yield. Water depth did not influence any of the variables studied, for the maize hybrids included in this experiment.

2. Hybrid 2B810 showed a higher mean yield and lower incidence of disease. The incidence of disease was directly correlated with maize crop yield.

\section{Literature Cited}

Agostinho, J. M. F. S. O aumento da rentabilidade do milho no minho: Eficiência do uso da água e redução dos custos associados a rega e fertilização. Revista de Ciências Agrárias, v.34, p.24-41, 2011.

Allen, R. G.; Pereira, L. S.; Raes, D.; Smith, M. Crop evapotranspiration. Rome: FAO, 1998. 301p. FAO. Irrigation Paper, 56

Ben, L. H. B.; Peiter, M. X.; Robaina, A. D.; Kirchner, J. H.; Mezzomo, W.; Pimenta, B. D. Agronomic performance of maize hybrids under supplemental irrigation depths. Revista Brasileira de Engenharia Agrícola e Ambiental, v.23, p.524-531, 2019. https:// doi.org/10.1590/1807-1929/agriambi.v23n7p524-531

Ben, L. H. B.; Peiter, M. X.; Robaina, A. D.; Parizi, A. R. C.; Silva, G. U. S. da. Influence of irrigation levels and plant density on "second-season" maize. Revista Caatinga, v.29, p.665-676, 2016. https://doi.org/10.1590/1983-21252016v29n317rc

Bergamaschi, H.; Dalmago, G. A.; Bergonci, J. I.; Bianchi, C. A. M.; Müller, A. G.; Comiran, F.; Heckler, B.M.M. Distribuição hídrica no período crítico do milho e produção de grãos. Pesquisa Agropecuária Brasileira, v.39, p.831-839, 2004. https://doi. org/10.1590/S0100-204X2004000900001
Bergamaschi, H.; Dalmago, G. A.; Comiran, F.; Bergonci, J. I; Muller, A. G.; França, S.; Santos, A. O.; Radin, B.; Bianchi, C. A. M.; Pereira, P. G. Déficit hídrico e produtividade na cultura do milho. Pesquisa Agropecuária Brasileira, v.41, p.243-249, 2006. https:// doi.org/10.1590/S0100-204X2006000200008

Bhering, L. L. RBIO: A tool for biometric and statistical analysis using the R Platform. Crop Breeding and Applied Biotechnology, v.17, p.187-190, 2017. https://doi.org/10.1590/1984-70332017v17n2s29

Costa, M. L. N.; Machado, J. da C.; Guimarães, R. M.; Pozza, E. A.; Oride, D. Inoculation of bean seeds with Fusarium oxysporum f. sp. Phaseoli through water restriction technique. Ciência e Agrotecnologia, v.27, p.1023-1030, 2003. https://doi.org/10.1590/ S1413-70542003000500008

Detomini, E. R.; Massignam, L. F. D.; Libardi, P. L.; Dourado Neto, D. Consumo hídrico e coeficiente de cultura para o híbrido DKB 390. Acta Scientiarum. Agronomy, v.31, p.445-452, 2009. https:// doi.org/10.4025/actasciagron.v31i3.379

Doorenbos, J.; Kassam, A. H. Efeito da água no rendimento das culturas. Campina Grande: UFPB. 1994. 306p. Estudos FAO. Irrigação e Drenagem, 33

Gava, R.; Snyder, R. L.; Frizzone, J. A.; Kühn, I. E.; Cotrim, M. F.; Piati, G. L. Maize second season irrigated by center pivot in sandy soil. Revista Brasileira de Agricultura Irrigada, v.12, p.2554-2560, 2018. https://doi.org/10.7127/rbai.v12n200825

Kamana, H.; Kirda, C.; Sesverenc, S. Genotypic differences of maize in grain yield response to deficit irrigation. Agricultural Water Management, v.98, p.801-807, 2011. https://doi.org/10.1016/j. agwat.2010.12.003

Kappes, C.; Andrade, J. A. da C.; Arf, O.; Oliveira, A. C. de; Arf, M. V.; Ferreira, J. P. Desempenho de híbridos de milho em diferentes arranjos espaciais de plantas. Bragantia, v.70, p.334-343, 2011. https://doi.org/10.1590/S0006-87052011000200012

Langner, J. A.; Zanon, A. J.; Streck, N. A.; Reiniger, L. R. S.; Kaufmann, M. P.; Alves, A. F. Maize: Key agricultural crop in food security and sovereignty in a future with water scarcity. Brazilian Journal of Agricultural and Environmental Engineering, v.23, p.648-654, 2019. https://doi.org/10.1590/1807-1929/agriambi. v23n9p648-654

Martin, J. D.; Carlesso, R.; Aires, N. P.; Gatto, J. C.; Dubou, V.; Fries, H. M.; Scheibler, R. B. Irrigação deficitária para aumentar a produtividade da água na produção de silagem de milho. Irriga, p.192-205, 2012. https://doi.org/10.15809/irriga.2012v1n01p192

Martínez, M.; Arata, A. F.; Lázaro, L.; Stenglein, S. A.; Dinolfo, M. I. Effects of waterlogging stress on plant-pathogen interaction between Fusarium poae and wheat/ barley. Acta Scientiarum. Agronomy, v.41, p.1-9, 2019. https://doi.org/10.4025/actasciagron. v41i1.42629

Munkvold, G. P. Epidemiology of Fusarium diseases and their mycotoxins in maize ears. European Journal of Plant Pathology, v.109, p.705-713, 2003. https://doi.org/10.1007/978-94-0171452-5_5

Pereira, O. A. P.; Carvalho, R. V.; Camargo, L. E. A. Doenças do milho. In: Kimati, H., Amorim, L.; Rezende, J. A. M.; Bergamin Filho, A.; Camargo, L. E. A. (ed.). Manual de fitopatologia: Doenças de plantas cultivadas. Agronômica Ceres, v.2, p.477-488, 2005.

Pinto, N. F. J. de A. Grãos ardidos em milho. Sete Lagoas: Embrapa Milho e Sorgo, 2005. 6p. Circular Técnica, 66 
Pinto, N. F. J. de A. Reação de cultivares de milho à mancha foliar causada por Stenocarpella macrospora. Sete Lagoas: Embrapa Milho e Sorgo, 2006. 4p. Comunicado Técnico, 140

Ramos, D. P.; Barbosa, R. M.; Vieira, B. C. T. L.; Panizzi, R. de C.; Vieira, R. D. Infecção por Fusarium graminearum e Fusarium verticillioides em sementes de milho. Pesquisa Agropecuária Tropical, Goiânia, v.44, p.24-31, 2014. https://doi.org/10.1590/ S1983-40632014000100011

Roese, A. D.; Ribeiro Junior, P. J.; Silva, V. P da.; Mio, L. L. M. Agrosilvopastoral system enhances suppressiveness to soybean damping-off caused by Rhizoctonia solani and alters Fusarium and Trichoderma population density. Acta Scientiarum. Agronomy, v.40, p.1-11, 2018. https://doi.org/10.4025/actasciagron.v40i1.35075

Rosa, R. P.; Pittelkow, F. K.; Pasquall, R. M. Potencial produtivo de híbridos de milho em dois níveis tecnológicos. Fundação Rio Verde, 2015. Boletim Técnico safra 2014/2015

Rosa, R. P.; Pittelkow, F. K.; Pasquall, R. M. Competição de híbridos de milho de segunda safra. Fundação Rio Verde, 2017. Boletim Técnico safra 2016/2017

Sangoi, L.; Almeida, M. L.; Gracietti, M. A.; Bianchet, P. Sustentabilidade do colmo em híbridos de milho de diferentes épocas de cultivo em função da densidade de plantas. Revista de Ciências Agroveterinárias, v.1, p.60-66, 2002.
Santos, P. G.; Juliatti, F. C.; Buiatti, A. L.; Hamawaki, O. T. Avaliação do desempenho agronômico de híbridos de milho em Uberlândia, MG. Pesquisa Agropecuária Brasileira, v.37, p.597-602, 2002. https://doi.org/10.1590/S0100-204X2002000500004

Shioga, P. S.; Gerage, A. C.; Araújo, P. M.; Bianco, R.; Custódio, A. A. de P. Avaliação estadual de cultivares de milho segunda safra 2015. Londrina: Instituto Agronômico do Paraná, 2015. 107p. Boletim Técnico, 86

Stefanello, J.; Bachi, L. M. A.; Gavassoni, W. L.; Hirata, L. M.; Pontim, B. C. A. Incidência de fungos em grãos de milho em função de diferentes épocas de aplicação foliar de fungicida. Pesquisa Agropecuária Tropical, v.42, p.476-481, 2012. https:// doi.org/10.1590/S1983-40632012000400014

Vian, A. L.; Santi, A. L.; Amado, T. J. C.; Cherubin, M. R. C.; Simon, D. H.; Damian, J. M.; Bredemeier, C. Spatial variability of grain yield of irrigated corn and its correlation with explanatory plant variables. Ciência Rural, v.46, p.464-471, 2016. https://doi. org/10.1590/0103-8478cr20150539

Vieira, V. M.; Silva, P. R. F. da; Sangoi, L.; Castro, N. M. dos R.; Strider, M. L.; Jandrey, D. B; Endrigo, P. C; Serpa, M. da S.; Louzada, J. A. S. Rendimento de grãos de milho sob diferentes sistemas de irrigação por aspersão. Irriga, v.18, p.471-485, 2013. https://doi. org/10.15809/irriga.2013v18n3p471 